\title{
THE EFFECT OF FERTILIZATION AND GRAZING APPLICATIONS ON ROOT LENGTH AND ROOT BIOMASS OF SOME RANGELAND GRASSES
}

\author{
Tamer YAVUZ**1, Yasar KARADAG ${ }^{2}$ \\ ${ }^{1}$ Ahi Evran University, Faculty of Agriculture, Department of Field Crops, Kirşehir, TURKEY \\ ${ }^{2}$ Gaziosmanpaşa University, Faculty of Agriculture, Department of Field Crops, Tokat, TURKEY \\ *Corresponding author:tameryavuz551@hotmail.com
}

Received: 10.10 .2014

\begin{abstract}
It is important to know the effects of applications such as fertilization and grazing on the vegetation improvement of certain species. This study was conducted to examine the effect of grassland improvement by fertilization and grazing on root length and biomass of various grassland grasses (Festuca ovina L., Koeleria cristata (L.) Bertol, Chrysopogon gryllus (L.) Trin., Bothriochloa ischaemum L. Keng) of the Tokat province of Turkey in the years 2008 and 2009. Great variations were observed among grass species in all applications. All different fertilization and ungrazed applications increased root length and root biomass parameters. Root lengths and root biomass of the species varied from 8.16 to14.27 $\mathrm{cm}$ and from 0.73 to $4.73 \mathrm{~g}$, respectively. The longest root lengths and root biomass results were obtained from ungrazed land+ $75 \mathrm{~kg} \mathrm{ha}^{-1} \mathrm{~N}_{+} \mathrm{P}_{2} \mathrm{O}_{5}$ fertilization application.
\end{abstract}

Key Words: Belowground biomass, Fertilization, Rangeland, Grazing,

\section{INTRODUCTION}

Stockbreeding depends mainly on grasslands that have been overgrazed and grassland productivity has decreased in Turkey (Bakoglu et al., 1999a; Turk et al., 2014). A major portion of forage was supplied from low quality sources due to the insufficient production of quality forage crops (Koc et al., 2012). The requisite methods of rangeland improvement and management should be applied in order to increase their productivity and overgrazing should be decreased. In rangeland improvement, it is incredibly important to know the effects of many applications such as fertilization and protect from grazing regimes on rangeland vegetation in light of vegetation health and sustainability.

Based on the results of different practices under different conditions, it is quite difficult to determine the effects of pasture grazing and fertilization on rangeland vegetation. Current studies show significantly different results. Some researchers reported that grazing has no effect on root biomass (McNaughton et al., 1998; Hejduk and Hrabě, 2003; Pucheta et al.,2004); however, some have reported increases (Milchunas and Lauenroth, 1993; Frank et al., 2002), and others have reported decreases in root biomass (Tewari and Joshi, 1985; Milchunas and Lauenroth, 1989; Biondini et al., 1998; Johnson and Matchett, 2001; Gao et al., 2008; Bagchi and Ritchie, 2010; Gao et al., 2011; Nippert et al., 2012; Yan et al., 2013). Similar results can be seen in fertilization studies.
Ladwig et al. (2012) and Balogianni et al.(2014) indicated that fertilization does not affect root biomass. According to Glab and Kacorzyk (2011), fertilization leads to a decrease in root biomass. On the other hand, many researchers found that fertilization on rangeland leads to an increase in root biomass (Tewari and Joshi, 1985; Gonzalez et al., 2002; Beebe et al., 2002; Hejduk and Hrabě, 2003; Rajaniemi et al., 2003; Heggenstaller et al., 2009).

Considering recent studies, the effects of fertilization and grazing on rangeland vegetation should be investigated under different ecological conditions and the results must be evaluated to its own conditions. Therefore, the aim of the current study was to determine the effect of fertilization and grazing applications on root length and root biomass of some grasses in the natural rangelands of Turkey.

\section{MATERIALS AND METHODS}

The grasses included in the study were the natural grasslands of the Tokat province of Turkey $\left(40^{\circ} 19^{\prime} 23^{\prime \prime} \mathrm{N}\right.$, $\left.36^{\circ} 28^{\prime} 50^{\prime \prime} \mathrm{E}\right)$. These grasslands are located in nearly 750 meters above mean sea level and on the north aspect of the hills. Annual temperature means were $12.0^{\circ} \mathrm{C}$ and $13.1{ }^{\circ} \mathrm{C}$ in the years 2008 and 2009 , respectively. The long-term temperature mean is $12.4{ }^{\circ} \mathrm{C}$. Total precipitation in 2008 and 2009 and long-term precipitation values were 471.2 $\mathrm{mm}, 592.9 \mathrm{~mm}$, and $448.2 \mathrm{~mm}$, respectively. The soil was 
sandy-loam, non-saline, and had $\mathrm{pH}$ of 7.65; the available phosphorous was $0.85 \mathrm{~kg} \mathrm{da}^{-1}$, available potassium was $55.3 \mathrm{~kg} \mathrm{da}^{-1}$, and organic matter was $3.61 \%$.

The experiment was conducted in 2008 and 2009 according to a randomized complete block design with three replicates. The plot area in the experiment was a 50 $\mathrm{m}^{2}(5 \times 10 \mathrm{~m})$ block and plot spaces were $1 \mathrm{~m}$. A total of six applications were implemented, which included: grazed $(\mathrm{G})$, ungrazed (UG; protected from grazing and unfertilized), ungrazed $+50 \mathrm{~kg} \mathrm{ha}{ }^{-1} \mathrm{P}_{2} \mathrm{O}_{5}\left(\mathrm{UG}+\mathrm{F}_{1}\right)$, ungrazed $+75 \mathrm{~kg} \mathrm{ha}^{-1} \mathrm{P}_{2} \mathrm{O}_{5}\left(\mathrm{UG}+\mathrm{F}_{2}\right)$, ungrazed $+50 \mathrm{~kg} \mathrm{ha}^{-}$ ${ }^{1} \mathrm{~N}+\mathrm{P}_{2} \mathrm{O}_{5}\left(\mathrm{UG}+\mathrm{F}_{3}\right)$, and ungrazed $+75 \mathrm{~kg} \mathrm{ha}^{-1} \mathrm{~N}+$ $\mathrm{P}_{2} \mathrm{O}_{5}\left(\mathrm{UG}+\mathrm{F}_{4}\right)$. The experimental area was fenced by barbed wire on March 1, 2007 for grazing preservation during the experimental period. Control plots for the grazing application were outside of this fenced area. Fertilizer was applied on April 1 in the years 2007, 2008, and 2009.

During study, ten plant samples from each dominant species (Festuca ovina L., Koeleria cristata L. Bertol, Chrysopogon gryllus (L.) Trin., Bothriochloa ischaemum (L.) Keng) with their roots were obtained from all plots at the end of the vegetation period using a spade. All samples were washed in a bucket. Root lengths and weights of the washed samples were measured. The average root lengths and biomass were calculated for each plant. Then, the plants were cut from root necks. The roots were dried at $70{ }^{\circ} \mathrm{C}$ for $48 \mathrm{~h}$ to determine the root biomass. The obtained data were analyzed by using SAS Version 8.0 (SAS Institute, 1999) statistical program and LSD values were calculated.

\section{RESULTS AND DISCUSSION}

\section{Root Length}

In both years of the experiment, root lengths were also statistically different concerning both grass forage species and applications (Table 1). The longest root length was measured $(11.42 \mathrm{~cm})$ in the C. Gryllus species and the shortest root length was $9.90 \mathrm{~cm}$ in $K$. cristata in 2008; whereas the longest root length was measured $(12.91 \mathrm{~cm})$ in the $C$. gryllus species and the shortest root length was $11.21 \mathrm{~cm}$ in $K$. cristata in 2009 . In addition, the longest root length $(12.97 \mathrm{~cm})$ in the first year was measured in the plots with $\mathrm{UG}+\mathrm{F}_{4}$ application and the shortest root length $(8.08 \mathrm{~cm})$ was measured in the $\mathrm{G}$ application. In the second year of the experiment, root lengths varied from $8.24(\mathrm{G})$ to $15.57 \mathrm{~cm}\left(\mathrm{UG}+\mathrm{F}_{4}\right)$ (Table 1$)$.

Table 1. Effect of applications on root length of some grass species $\left(\mathrm{cm} \mathrm{plant}^{-1}\right)$

\begin{tabular}{|c|c|c|c|c|c|c|c|c|c|c|}
\hline \multirow{3}{*}{$\begin{array}{l}\text { Applications } \\
\mathrm{G}^{*}\end{array}$} & \multicolumn{2}{|c|}{ Festuca ovina } & \multicolumn{2}{|c|}{ Koeleria cristata } & \multirow{2}{*}{\multicolumn{2}{|c|}{$\begin{array}{c}\text { Chrysopogon gryllus } \\
\mathbf{2 0 0 8}\end{array}$}} & \multicolumn{2}{|c|}{ Bothriochloa ischaemum } & \multicolumn{2}{|c|}{ Means } \\
\hline & & & & & & & & & & \\
\hline & 8.77 & $\mathrm{~h}_{\mathrm{ij}}^{\dagger}$ & 6.87 & $\mathrm{k}$ & 8.97 & hij & 7.73 & $\mathrm{jk}$ & 8.08 & $\mathrm{e}^{*}$ \\
\hline UG & 10.63 & $\mathrm{~d}-\mathrm{g}$ & 8.30 & ijk & 11.17 & $c-f$ & 8.97 & hij & 9.77 & $\mathrm{~d}$ \\
\hline $\mathrm{UG}+\mathrm{F}_{1}$ & 9.97 & $e-h$ & 9.83 & fgh & 11.30 & cde & 10.20 & $e-h$ & 10.32 & $\mathrm{~d}$ \\
\hline $\mathrm{UG}+\mathrm{F}_{2}$ & 12.20 & $a b c$ & 11.97 & bcd & 12.87 & $a b$ & 11.40 & cde & 12.11 & $\mathrm{~b}$ \\
\hline $\mathrm{UG}+\mathrm{F}_{3}$ & 11.20 & $c-f$ & 9.54 & gh1 & 11.77 & bcd & 11.90 & bcd & 11.10 & $\mathrm{c}$ \\
\hline $\mathrm{UG}+\mathrm{F}_{4}$ & 13.57 & $\mathrm{a}$ & 12.87 & $\mathrm{ab}$ & 12.43 & $a b c$ & 13.00 & $a b$ & 12.97 & $\mathrm{a}$ \\
\hline \multirow[t]{2}{*}{ Means } & 11.06 & $\mathrm{AB}^{\pi}$ & 9.90 & $\mathrm{C}$ & 11.42 & A & 10.53 & $\mathrm{~B}$ & 10.73 & \\
\hline & \multicolumn{10}{|c|}{2009} \\
\hline $\mathrm{G}$ & 8.87 & $\mathrm{~m}$ & 7.47 & $\mathrm{n}$ & 9.17 & $\operatorname{lm}$ & 7.47 & $\mathrm{n}$ & 8.24 & $\mathrm{f}$ \\
\hline UG & 10.70 & $1 \mathrm{j}$ & 9.83 & $\mathrm{kl}$ & 11.87 & $\mathrm{~h}$ & 10.43 & $\mathrm{jk}$ & 10.71 & $\mathrm{e}$ \\
\hline $\mathrm{UG}+\mathrm{F}_{1}$ & 11.37 & $\mathrm{~h}_{1}$ & 11.47 & $\mathrm{~h}$ & 12.87 & $\mathrm{~g}$ & 11.37 & $h_{1}$ & 11.77 & $\mathrm{~d}$ \\
\hline $\mathrm{UG}+\mathrm{F}_{2}$ & 14.00 & de & 13.07 & $\mathrm{~g}$ & 15.00 & $\mathrm{c}$ & 13.43 & efg & 13.88 & $\mathrm{~b}$ \\
\hline $\mathrm{UG}+\mathrm{F}_{3}$ & 12.97 & g & 11.20 & h1 & 13.10 & fg & 13.83 & def & 12.77 & $\mathrm{c}$ \\
\hline $\mathrm{UG}+\mathrm{F}_{4}$ & 16.63 & $\mathrm{a}$ & 14.23 & $\mathrm{~d}$ & 15.47 & $\mathrm{bc}$ & 15.97 & $\mathrm{ab}$ & 15.57 & $\mathrm{a}$ \\
\hline \multirow[t]{2}{*}{ Means } & 12.42 & B & 11.21 & $\mathrm{D}$ & 12.91 & A & 12.08 & $\mathrm{C}$ & 12.16 & \\
\hline & \multicolumn{10}{|c|}{ Mean of 2-year } \\
\hline $\mathrm{G}$ & 8.82 & 1 & 7.17 & $\mathrm{~m}$ & 9.07 & $\mathrm{kl}$ & 7.60 & $\mathrm{~m}$ & 8.16 & $\mathrm{f}$ \\
\hline UG & 10.67 & 1 & 9.07 & $\mathrm{kl}$ & 11.52 & gh & 9.70 & $\mathrm{jk}$ & 10.24 & $\mathrm{e}$ \\
\hline $\mathrm{UG}+\mathrm{F}_{1}$ & 10.67 & 1 & 10.65 & $\mathrm{i}$ & 12.08 & $\mathrm{fg}$ & 10.78 & h1 & 11.05 & d \\
\hline $\mathrm{UG}+\mathrm{F}_{2}$ & 13.10 & de & 12.52 & ef & 13.93 & bc & 12.42 & ef & 12.99 & $\mathrm{~b}$ \\
\hline $\mathrm{UG}+\mathrm{F}_{3}$ & 12.08 & fg & 10.37 & $\mathrm{ij}$ & 12.43 & ef & 12.87 & def & 11.94 & c \\
\hline $\mathrm{UG}+\mathrm{F}_{4}$ & 15.10 & $\mathrm{a}$ & 13.55 & $\mathrm{~cd}$ & 13.95 & bc & 14.48 & $a b$ & 14.27 & $\mathrm{a}$ \\
\hline Means & 11.74 & B & 10.55 & D & 12.16 & A & 11.31 & $\mathrm{C}$ & 11.45 & \\
\hline
\end{tabular}

${ }^{\dagger}$ Same letter(s) in the same columns and lines are not different. ${ }^{\star}$ Same letter(s) in the same columns are not different. Same letter(s) in the same lines are not different.

$* \mathrm{G}$ : grazed

UG; ungrazed (protected from grazing and unfertilized)

$\mathrm{UG}+\mathrm{F}_{1}$ : ungrazed $+50 \mathrm{~kg} \mathrm{ha}^{-1} \mathrm{P}_{2} \mathrm{O}_{5}$

$\mathrm{UG}+\mathrm{F}_{2}$ : ungrazed $+75 \mathrm{~kg} \mathrm{ha}^{-1} \mathrm{P}_{2} \mathrm{O}_{5}$

$\mathrm{UG}+\mathrm{F}_{3}$ : ungrazed $+50 \mathrm{~kg} \mathrm{ha}^{-1} \mathrm{~N}+\mathrm{P}_{2} \mathrm{O}_{5}$

$\mathrm{UG}+\mathrm{F}_{4}$ : ungrazed $+75 \mathrm{~kg} \mathrm{ha}^{-1} \mathrm{~N}+\mathrm{P}_{2} \mathrm{O}_{5}$ 
According to two-year means, the root lengths showed a statistically significant difference $(\mathrm{p}<0.01)$ among the grass species (Table 1). The longest root length mean $(12.16 \mathrm{~cm})$ was in $C$. gryllus; while the shortest root length $(10.55 \mathrm{~cm})$ was determined in $K$. cristata. The effect of the applications on root length was statistically significant ( $p<0.01$ ). The root lengths increased with applications. The longest root length $(14.27 \mathrm{~cm})$ was in the $\mathrm{UG}+\mathrm{F}_{4}$ application, whereas the shortest root length $(8.16 \mathrm{~cm})$ was determined in the $\mathrm{G}$ application (Table 1).

Species $\mathrm{x}$ application and year $\mathrm{x}$ application interactions were statistically significant $(p<0.01)$ in the study. The significant interaction between years and applications indicates that the fertilizer applications did not have an effect on the root length increases in both years simultaneously. Therefore, the mean root length in the UG application was not statistically different from the mean root length in the $\mathrm{UG}+\mathrm{F}_{1}$ application in 2008 ; however, there was a statistically difference between root lengths in the UG and $\mathrm{UG}+\mathrm{F}_{1}$ applications $(\mathrm{p}<0.01)$ in 2009. On the other hand, the root lengths of $F$. ovina, $K$. cristata, $C$. gryllus, and B. ischaemum species were 11.06 $\mathrm{cm}, 9.90 \mathrm{~cm}, 11.42 \mathrm{~cm}$, and $10.53 \mathrm{~cm}$, respectively in 2008; while they were measured as $12.42 \mathrm{~cm}, 11.21 \mathrm{~cm}$, $12.91 \mathrm{~cm}$, and $12.08 \mathrm{~cm}$, respectively, in 2009 . It can be said that these differences were caused by precipitation during the experiment period, which implies that available fertilizer might increase owing to precipitation for plants (Table 1).

According to the results of the present study, plant root length increased significantly with fertilization, ungrazing, and the combination of the two compared with continuously grazed and unfertilized plots. Therefore, it is possible to claim that fertilization and ungrazing have a positive effect on root length. Indeed, heavy grazing reduces root growth and length (Johnson and Matchett, 2001; Nippert et al., 2012). In contrast to Glab and Kacorzyk (2011), the longest root length was obtained from non-fertilized control plots. According to Milchunas and Lauenroth (1989), grazing has little effect on the vertical development of root biomass, but has significant effects on the horizontal development. Frank et al. (2002) reported that herbivores have a positive effect on root growth and Bonin et al., (2013) reported that root length is increased by grazing on the soil surface. Results related to root length, and differences between other studies may be caused by different botanical compositions and ecological conditions in grasslands (Gibson et al., 1993; Pucheta et al.,2004) or different responses of species to different applications (Heggenstaller et al., 2009; Kohyani et al., 2009).

\section{Root Biomass}

Root biomass values were statistically different $(\mathrm{p}<$ 0.01 ) regarding both grass species and applications in both years. The highest root biomass $(8.22 \mathrm{~g})$ was measured in $F$. ovina and the lowest root biomass $(0.49 \mathrm{~g})$ was in $K$. cristata in 2008; whereas these values were 9.63 and 0.56 $\mathrm{g}$ in the same species in 2009 (Table 2). Evaluating the effect of the fertilizer applications, the highest root biomass was $4.08 \mathrm{~g}$ with the $\mathrm{UG}+\mathrm{F}_{2}$ application and the lowest root biomass $(0.73 \mathrm{~g})$ was measured in the $G$ application in 2008. The lowest and highest root biomasses varied from $0.74 \mathrm{~g}$ in the $\mathrm{G}$ application to 5.43 $\mathrm{g}$ in the $\mathrm{UG}+\mathrm{F}_{4}$ application in 2009 (Table 2).

According to the two-year means, root biomass showed a statistically significant difference $(p<0.01)$ regarding both the grass species and applications. The highest root biomass $(8.79 \mathrm{~g})$ was in $F$. ovina, while the lowest root biomass $(0.52 \mathrm{~g})$ was determined in $K$. cristata. The highest root biomass $(4.73 \mathrm{~g})$ was in the $\mathrm{UG}+\mathrm{F}_{4}$ application, whereas the lowest root biomass $(0.73 \mathrm{~g})$ was determined in the $\mathrm{G}$ application. Root biomass increased in the ungrazed and fertilization combinations, but decreased in the grazing application (Table 2).

Species $\mathrm{x}$ application, species $\mathrm{x}$ year, application $\mathrm{x}$ year, and species $\mathrm{x}$ application $\mathrm{x}$ year interactions were statistically significant $(\mathrm{p}<0.01)$ in the study. The reason that the year $\mathrm{x}$ interaction was statistically significant was due to different reactions of years to different fertilizer doses. As a matter fact, root biomass, which was determined in $\mathrm{UG}+\mathrm{F}_{1}$, was not statistically different from the root biomass in $\mathrm{UG}+\mathrm{F}_{3}$ and $\mathrm{UG}+\mathrm{F}_{4}$ applications in 2008; however, it was statistically different $(\mathrm{p}<0.01)$ in 2009 (Table 2). The effect of the grass species on root biomass was statistically different in both years. In the first year the study, dry root weights of $F$. ovina, $K$. cristata, C. gryllus, and B. ischaemum species were 8.22 $\mathrm{g}, 0.49 \mathrm{~g}, 1.09 \mathrm{~g}$, and $1.80 \mathrm{~g}$, respectively; these values were $9.63 \mathrm{~g}, 0.56 \mathrm{~g}, 1.27 \mathrm{~g}$, and $2.57 \mathrm{~g}$, respectively, in 2009. These high values in 2009 were caused by climate conditions, especially high precipitation. Furthermore, high temperature with precipitation in the second year increased the available fertilizer (Sun et al., 2008).

The results demonstrated that the effect of the applications on root biomass rise parallel to the effects on root length. While grazing reduced root biomass, fertilization and protection from grazing practices increased root biomass. Grazing had a negative effect on below-ground and above-ground biomass of the grasslands (Yan et al., 2013), and therefore the production of biomass decreased (Nippert et al., 2012; Gaoet al., 2008 and 2011). Controversially, some researchers reported that grazing does not affect root biomass (McNaughton et al., 1998; Pucheta et al., 2004). Root growth has been reported to be reduced by heavy grazing $(-30 \%)$ (Johnson and Matchett, 2001) and the below-ground production of grassland plants was reduced by intensive grazing $(-35 \%)$ (Bagchi and Ritchie, 2010). Schuster (1964) indicated that the root biomass of grasses in ungrazed pastures were significantly higher than those in medium or heavily grazed pastures, and increases in grazing pressure caused remarkable decreases in the root biomass of grasses. Furthermore, according to Rogers et al. (2005), medium or heavy grazing resulted in a reduction of total root biomass, but heavy grazing had a affected the decrease more significantly than medium grazing. Bakoglu et 
al.(1999b) reported that the below-ground biomass of in Koeleria cristata these values ranged from $6.63 \mathrm{~g}$ to Festuca ovina ranged from $6.17 \mathrm{~g}$ to $23.34 \mathrm{~g} \mathrm{plant}^{-1}$, while $20.74 \mathrm{~g} \mathrm{plant}^{-1}$.

Table 2. Effect of applications on root biomass of some grass species $\left(\mathrm{g}\right.$ plant $\left.{ }^{-1}\right)$

\begin{tabular}{|c|c|c|c|c|c|c|c|c|c|c|}
\hline \multirow[t]{2}{*}{ Applications } & \multicolumn{2}{|c|}{ Festuca ovina } & \multirow{2}{*}{\multicolumn{2}{|c|}{ Koeleria cristata }} & \multirow{2}{*}{\multicolumn{2}{|c|}{$\frac{\text { Chrysopogon gryllus }}{\mathbf{2 0 0 8}}$}} & \multirow{2}{*}{\multicolumn{2}{|c|}{ Bothriochloa ischaemum }} & \multicolumn{2}{|c|}{ Means } \\
\hline & & & & & & & & & & \\
\hline G & 1.42 & $\mathrm{~h}^{\dagger}$ & 0.22 & $\mathrm{~m}$ & 0.43 & $\operatorname{lm}$ & 0.83 & $\mathrm{jk}$ & 0.73 & $d^{*}$ \\
\hline UG & 3.49 & $\mathrm{~d}$ & 0.36 & $1 \mathrm{~m}$ & 0.82 & $\mathrm{jk}$ & 1.44 & gh & 1.53 & $\mathrm{c}$ \\
\hline $\mathrm{UG}+\mathrm{F}_{1}$ & 10.64 & c & 0.46 & $\operatorname{lm}$ & 1.29 & $\mathrm{~h}$ & 1.73 & fg & 3.53 & $\mathrm{~b}$ \\
\hline $\mathrm{UG}+\mathrm{F}_{2}$ & 12.06 & $\mathrm{a}$ & 0.55 & $\mathrm{kl}$ & 1.40 & $\mathrm{~h}$ & 2.31 & $\mathrm{e}$ & 4.08 & $\mathrm{a}$ \\
\hline $\mathrm{UG}+\mathrm{F}_{3}$ & 10.47 & $\mathrm{c}$ & 0.47 & $\operatorname{lm}$ & 1.15 & $h_{1}$ & 1.89 & $\mathrm{f}$ & 3.50 & $\mathrm{~b}$ \\
\hline $\mathrm{UG}+\mathrm{F}_{4}$ & 11.22 & b & 0.88 & ij & 1.42 & $\mathrm{~h}$ & 2.61 & $\mathrm{e}$ & 4.03 & $\mathrm{~b}$ \\
\hline \multirow[t]{2}{*}{ Means } & 8.22 & $\mathrm{~A}^{*}$ & 0.49 & $\mathrm{D}$ & 1.09 & $\mathrm{C}$ & 1.80 & B & 2.90 & \\
\hline & \multicolumn{10}{|c|}{2009} \\
\hline G & 1.46 & $1 \mathrm{j}$ & 0.24 & $\mathrm{n}$ & 0.45 & $\mathrm{mn}$ & 0.78 & $1 \mathrm{~m}$ & 0.74 & $\mathrm{f}$ \\
\hline UG & 3.48 & $\mathrm{f}$ & 0.45 & $\mathrm{mn}$ & 0.91 & klm & 1.70 & 1 & 1.64 & $\mathrm{e}$ \\
\hline $\mathrm{UG}+\mathrm{F}_{1}$ & 10.90 & $\mathrm{~d}$ & 0.52 & $\mathrm{mn}$ & 1.53 & 1 & 2.40 & $\mathrm{~h}$ & 3.84 & $\mathrm{~d}$ \\
\hline $\mathrm{UG}+\mathrm{F}_{2}$ & 13.62 & $\mathrm{~b}$ & 0.61 & $\operatorname{lmn}$ & 1.67 & 1 & 3.16 & fg & 4.77 & $\mathrm{~b}$ \\
\hline $\mathrm{UG}+\mathrm{F}_{3}$ & 12.26 & $\mathrm{c}$ & 0.51 & $\mathrm{mn}$ & 1.35 & $1 \mathrm{jk}$ & 2.86 & gh & 4.24 & $\mathrm{c}$ \\
\hline $\mathrm{UG}+\mathrm{F}_{4}$ & 14.45 & $\mathrm{a}$ & 1.02 & $\mathrm{jkl}$ & 1.72 & 1 & 4.51 & $\mathrm{e}$ & 5.43 & $\mathrm{a}$ \\
\hline \multirow[t]{2}{*}{ Means } & 9.63 & A & 0.56 & $\mathrm{D}$ & 1.27 & $\mathrm{C}$ & 2.57 & B & 3.44 & \\
\hline & \multicolumn{10}{|c|}{ Mean of 2-years } \\
\hline G & 1.44 & $\mathrm{~h}_{1}$ & 0.23 & $\mathrm{~m}$ & 0.44 & $\operatorname{lm}$ & 0.81 & $\mathrm{jk}$ & 0.73 & $f$ \\
\hline UG & 3.49 & $\mathrm{~d}$ & 0.41 & $1 \mathrm{~m}$ & 0.87 & j & 1.57 & $\mathrm{~h}$ & 1.58 & $\mathrm{e}$ \\
\hline $\mathrm{UG}+\mathrm{F}_{1}$ & 10.77 & $\mathrm{c}$ & 0.49 & $1 \mathrm{~m}$ & 1.41 & $\mathrm{~h}_{1}$ & 2.07 & $\mathrm{~g}$ & 3.68 & d \\
\hline $\mathrm{UG}+\mathrm{F}_{2}$ & 12.84 & $\mathrm{a}$ & 0.58 & kl & 1.54 & $\mathrm{~h}$ & 2.74 & $\mathrm{e}$ & 4.42 & b \\
\hline $\mathrm{UG}+\mathrm{F}_{3}$ & 11.37 & b & 0.49 & $\operatorname{lm}$ & 1.25 & 1 & 2.38 & $\mathrm{f}$ & 3.87 & $\mathrm{c}$ \\
\hline $\mathrm{UG}+\mathrm{F}_{4}$ & 12.83 & $\mathrm{a}$ & 0.95 & j & 1.57 & $\mathrm{~h}$ & 3.56 & d & 4.73 & $\mathrm{a}$ \\
\hline Means & 8.79 & A & 0.52 & $\mathrm{D}$ & 1.18 & $\mathrm{C}$ & 2.19 & B & 3.17 & \\
\hline
\end{tabular}

${ }^{\dagger}$ Same letter(s) in the same columns and lines are not different. ${ }^{*}$ Same letter(s) in the same columns are not different. Same letter(s) in the same lines are not different.

*G: grazed

UG; ungrazed (protected from grazing and unfertilized)

$\mathrm{UG}+\mathrm{F}_{1}$ : ungrazed $+50 \mathrm{~kg} \mathrm{ha}^{-1} \mathrm{P}_{2} \mathrm{O}_{5}$

$\mathrm{UG}+\mathrm{F}_{2}$ : ungrazed $+75 \mathrm{~kg} \mathrm{ha}^{-1} \mathrm{P}_{2} \mathrm{O}_{5}$

$\mathrm{UG}+\mathrm{F}_{3}$ : ungrazed $+50 \mathrm{~kg} \mathrm{ha}^{-1} \mathrm{~N}+\mathrm{P}_{2} \mathrm{O}_{5}$

$\mathrm{UG}+\mathrm{F}_{4}$ : ungrazed $+75 \mathrm{~kg} \mathrm{ha}^{-1} \mathrm{~N}+\mathrm{P}_{2} \mathrm{O}_{5}$

In general, nitrogen fertilizers significantly increase the yield capacity of grasslands. Nitrogen is the main soil element that limits the productivity of grasslands. The efficiency of nitrogen depends on many factors such as climatic conditions, vegetation types, structure and form of soils, and the application frequency and quantity of fertilization (Sun et al., 2008). Heggenstaller et al. (2009) emphasized that nitrogen fertilization has a positive effect on yieldand root biomass of grasses. In addition, some studies have reported that fertilization increases root biomass (Tewari and Joshi, 1985; Rajaniemi et al., 2003; Tomaškin et al., 2013); nevertheless, low dose fertilization increases root biomass and high doses cause a decrease (Holub et al., 2013). The data of the current study differed from other researchers (Pucheta et al., 2004; Glab and Kacorzyk, 2011; Ladwig et al., 2012; Balogianni et al., 2014), due to different environmental conditions and management applications (Nippert et al., 2012; Yan et al., 2013), different amounts of fertilizer (Holub et al., 2013) and different grazing intensity and ungrazing applications (McNaughton et al., 1998).

\section{CONCLUSION}

Fertilizer applications combinations with ungrazing affected root length and biomass of grass species positively. Results show that root length and biomass increased with fertilization and ungrazing of the grassland. Consequently, it is possible to suggest that grazing has an adverse effect on root biomass and $75 \mathrm{~kg}$ $\mathrm{ha}^{-1} \mathrm{~N}+\mathrm{P} 2 \mathrm{O}$, as the most effective fertilizer dose, might be recommended to increase root length and root biomass of grasslands that have similar vegetation characteristics.

\section{LITERATURE CITED}

Bagchi, S. and M.E. Ritchie. 2010. Herbivore effects on aboveand belowground plant production and soil nitrogen availability in the Trans-Himalayan shrub-steppes. Oecologia. 164: 1075-1082.

Bakoglu, A., A. Koc and A. Gokkus. 1999a. Some characteristics of the common plants of range and meadows in Erzurum in relation to life span, beginning of the flowering and forage quality. Turk. J. Agric. For. 23: 951957. 
Bakoglu, A., A. Koc and A., Gokkus. 1999b. Variation in biomass and chemical composition of dominant rangeland plants during the growing season: I. Changes in biomass, root/shoot ratio, stem, leaf, flower ratios. Turk. J. Agric. For. 23: 487-494.

Balogianni, V.G., S.D. Wilson, B.M.Vaness, A.S. Mac Dougall and B.D. Pinno. 2014. Different root and shoot responses to mowing and fertility in native and invaded grassland. Rangeland Ecol. Manag. 67: 39-45.

Beebe, J., R. Everett, G. Scherer and C. Davis. 2002. Effect of fertilizer applications and grazing exclusion on species composition and biomass in wet meadow restoration in eastern Washington. Res. Pap. PNW-RP-542. Portland, OR U.S. Department of Agriculture, Forest Service, Pacific Northwest Research Station. 15 p.

Biondini, M.E., B.D. Patton and P.E. Nyren. 1998. Grazing intensity and ecosystem processes in Northern Mixed-Grass Prairie, USA. Ecol. Appl.8: 469-479.

Bonin, C., J. Flores, R. Lal and B. Tracy. 2013. Root characteristics of perennial warm-season grasslands managed for grazing and biomass production. Agronomy. 3: 508-523.

Frank, D.A., M.M. Kuns, and D.R. Guido. 2002. Consumer control of grassland plant production. Ecology. 83: 602-606.

Gao, Y.Z., M. Giese, S. Lin, F. Taube and H. Brueck. 2008 Belowground net primary productivity and biomass allocation of grassland in Inner Mongolia as affected by grazing intensity. Plant Soil. 307: 41-50.

Gao Y.Z., Q. Chen, S. Lin, M. Giese and H. Brueck. 2011 Resource manipulation effects on net primary production, biomass allocation and rain-use efficiency of two semiarid grassland sites in Inner Mongolia, China. Oecologia. 165: 855-864.

Gibson, D.J., T.R. Seastedt and J.M. Briggs. 1993. Management practices in tallgrass prairie: large- and small-scale experimental effects on species composition. J. Appl. Ecol. 30: 247-255.

Glab, T. and P. Kacorzyk. 2011. Root distribution and herbage production under different management regimes of mountain grassland. Soil. Till. Res. 113: 99-104.

Gonzalez R.M, R.E. Sosebee and C. Wan. 2002. Shoot and root biomass of desert grasses as affected by biosolids application. J. Arid. Environ. $50: 477-488$.

Heggenstaller, A.H., K.J. Moore, M. Liebman and R.P. Anex. 2009. Nitrogen influences biomass and nutrient partitioning by perennial, warm-season grasses. Agron. J. 101: 13631371.

Hejduk, S. And F. Hrabě. 2003. Influence of different systems of grazing, type of swards and fertilizing on underground phytomass of pastures. Plant. Soil. Environ. 49: 18-23.

Holub, P., I. Tůma and K. Fiala. 2013. Effect of fertilization on root growth in the wet submontane meadow. Plant Soil. Environ. 59: 342-347.

Johnson, C. and J.R. Matchett. 2001. Fire and grazing regulate belowground processes in tallgrass prairie. Ecology. 82: 3377-3389.

Koc, A., M. Tan, and H.I. Erkovan. 2012. An overview of fodder resources and animal production in Turkey. Options
Mediterranean, SerieA/102, New approaches for grassland research in a context of climate and socio-economic changes. Zaragoza, CIHEAM 542p.

Kohyani, P.T., B. Bossuyt, D. Bonte and M. Hoffmann.2009. Differential herbivory tolerance of dominant and subordinate plant species along gradients of nutrient availability and competition. Plant Ecol. 201: 611-619.

Ladwig, L., S. Collins, A. Swann, Y. Xia, M. Allen and E. Allen. 2012. Above- and below ground responses to nitrogen addition in a Chihuahuan Desert grassland. Oecologia 169: 177-185.

McNaughton S.J., F.F. Banyikwa, and M.M. McNaughton. 1998. Root biomass and productivity in a grazing ecosystem: the serengeti. Ecology 79: 587-592.

Milchunas D.G. and W.K. Lauenroth. 1989. Three-dimensional distribution of plant biomass in relation to grazing and topography in the short grass steppe. Oikos. 55: 82-86.

Milchunas D.G. and W.K. Lauenroth. 1993. A quantitative assessment of the effects of grazing on vegetation and soils over a global range of environments. Ecol. Monogr. 63: 32766.

Nippert J.B., R.A. Wieme, T.W. Ocheltree and J.M. Craine. 2012. Root characteristics of C4 grasses limit reliance on deep soil water in tall grass prairie. Plant Soil. 355: 385-394.

Pucheta, E., I. Bonamici, M. Cabido and S. Diaz. 2004. Belowground biomass and productivity of a grazed site and a neighboring ungrazed exclosure in a grassland in central Argentina. Austral Ecol. 29: 201-208.

Rajaniemi, T.K., V.J. Allison and D.E. Goldberg. 2003. Root competition can cause a decline in diversity with increased productivity. J. Ecol. 91: 407-416.

Rogers, W.M., D. R. Kirby, P.E. Nyren, B.D. Patton and E.S. Dekeyser. 2005. Grazing intensity effects on northern plains mixed-grass prairie. Prairie Nat. 37: 73-83.

SAS Institute. 1999. SAS Version 8.0. SAS Inst., Cary, NC.

Schuster, J.L. 1964. Root development of native plants under three grazing intensities. Ecology 45: 63-70.

Sun, X., N. Luo, B. Longhurst and J. Luo. 2008. Fertiliser nitrogen and factors affecting pasture responses. The Open Agric.J. 2:35-42.

Tewari M. and H. Joshi. 1985. Effect of nitrogen fertilizer on biomass and growth behavior of two range grasses. Plant Sci. 95: 41-46.

Tomaškin J., J. Jančovič, L. Vozar and J. Tomaškinova. 2013. The effect of mineral fertilization on belowground plant biomass of grassland ecosystems. Acta Universitatis Agriculturae et Silviculturae Mendelianae Brunensis, LXI (5) pp. 1431-1440.

Turk, M., S. Albayrak and Y. Bozkurt. 2014. Seasonal trends in chemical composition of different artificial pastures. Turkish Journal of Field Crops. 19(1): 53-58.

Yan, L., G. Zhou and F. Zhang. 2013. Effects of Different Grazing Intensities on Grassland Production in China: A Meta-Analysis. PLoS one, Available at: http://www.plosone.org/article/info\%3Adoi\%2F10.1371\%2F journal.pone.0081466 (Accessed: 25 April 2014) 